\title{
Vinasse biogas for energy generation in Brazil: An assessment of economic feasibility, energy potential and avoided $\mathrm{CO}_{2}$ emissions
}

\author{
Andressa Picionieri Bernal a, Ivan Felipe Silva dos Santos ${ }^{b,}{ }^{*}$, Ana Paula Moni Silva ${ }^{c}$, \\ Regina Mambeli Barros ${ }^{\mathrm{b}}$, Eruin Martuscelli Ribeiro ${ }^{\mathrm{c}}$ \\ ${ }^{a}$ São Paulo State University (EESC/USP), São Carlos, SP, Brazil \\ ${ }^{\mathrm{b}}$ Natural Resources Institute, Federal University of Itajubá (UNIFEI - MG), GEER - Renewable Energy Group, Brazil \\ ${ }^{\mathrm{c}}$ Natural Resources Institute, Federal University of Itajubá (UNIFEI MG), Brazil
}

\section{A R T I C L E I N F O}

\section{Article history:}

Received 24 September 2016

Received in revised form

9 March 2017

Accepted 9 March 2017

Available online 10 March 2017

\section{Keywords:}

Vinasse

Biogas

Electricity

Avoided $\mathrm{CO}_{2}$ emission

\begin{abstract}
A B S T R A C T
Energy recovery from waste is one of the strategies that can assist the expansion of renewable energy in Brazil. Among the various types of waste, vinasse, which is a residue that contains a high organic load, originates from the sugarcane industry, which is a very important industry for the Brazilian economy. Due to high levels of sugarcane harvesting in the country and the production of large amounts of ethanol, vinasse is produced at high levels in Brazil. In this context, this paper presents an energy analysis of the avoided carbon dioxide emissions and economic viability associated with the combustion of biogas produced by the anaerobic digestion of the vinasse that results from the use of sugar cane planted in Brazil. Based on the literature review, data related to the process of biogas production from anaerobic digestion of the vinasse were collected and used for the calculation of the energy potential associated. The results show that to achieve economic viability for the use of this waste for energy, the following plantation areas would be required, considering their processed sugarcane equivalents: 14,580 ha (if considering the processing of sugarcane in attached plants), and 6000 ha (if considering the processing of sugarcane in autonomous plants). The total energy potential of this use may reach $3.26 \mathrm{TWh}_{\mathrm{e}} / \mathrm{y}$, which represents $0.52 \%$ of all domestic energy consumption in 2014 . The potential to avoid emissions from the same use could reach $1.9 \mathrm{Mt} \mathrm{CO}_{2} / \mathrm{y}$, which is approximately $2.1 \%$ of the emissions for the whole industry in Brazil in 2014. These results demonstrate the environmental and energy benefits that can be obtained via power generation from biogas produced by the anaerobic digestion of vinasse and highlight the need to include the use of such residue for energy in expansion plans for the Brazilian energy matrix.
\end{abstract}

() 2017 Elsevier Ltd. All rights reserved.

\section{Introduction}

The need to reduce fossil fuel consumption and greenhouse gas emissions through the deployment of renewable energies and the diversification and expansion of the energy matrix are key issues for the energy planning of many countries. These goals are important for maintaining economic development while securing the energy supply.

The sugar cane is one of the main crops of the Brazilian economy. Brazil is not only the world's largest producer of sugar cane as

\footnotetext{
* Corresponding author.

E-mail addresses: andpbernal@hotmail.com (A.P. Bernal), ivanfelipedeice@ hotmail.com (I.F.S. dos Santos), anamoni@unifei.edu.br (A.P. Moni Silva), remambeli@hotmail.com (R.M. Barros), eruin.ribeiro@uol.com.br (E.M. Ribeiro).
}

it is also the first in the world in the sugar and ethanol production and conquest, increasingly, the foreign market with the use of biofuel as an alternative energy (BRAZIL, 2015). Within this scenario, sugarcane is one of the most promising sources for the generation of bioenergy in the Brazilian context, considering that sugarcane is harvested in the dry season (which includes the Brazilian' autumn and winter occurring between April and December, when the rainfall indices of the country are lowest), when hydroelectric generation, which is the main source of electricity in Brazil, being responsible for $64 \%$ of all electrical generation (percentage much higher than the second placed, the thermoelectric power, which is responsible for $22 \%$ of the national generation) (as presented by BEN, 2016), tends to be reduced (FUNDEP, 2016). In addition, the Brazilian sugar-ethanol sector has adapted to weather conditions and developed technology.

According to the Brazilian National Bank for Economic and 
Social Development (BNDES) and the Brazilian Center of Management and Strategic Studies (CGEE) (BNDES \& CGEE, 2008), sugarcane cultivation is the third most important resource in Brazil according to occupation area. Brazilian production of sugarcane is expected to grow $3.2 \%$ in the $2015 / 2016$ harvest in relation to the previous harvest, with an estimated harvest of $655.2 \mathrm{Mt}$ (CONAB, 2015). The Mid-South and Southeast have the highest production levels (approximately 85\%), and the State of São Paulo is the most prominent state, accounting for approximately $60 \%$ of the total production (Carvalho, 2007).

There are three types of sugarcane processing plant facilities: sugar mills (produce only sugar), sugar mills with annexed distilleries (produce sugar and ethanol), and autonomous distilleries (produce only ethanol). Sugar mills with annexed distilleries are the primary facilities in Brazil (account for approximately 68\% of the total sugarcane processed), while autonomous distilleries account for $28 \%$ of the total sugarcane processed, and the remaining sugarcane is processed by sugar processing units (NOVA CANA, w.d.).

Ethanol production from sugarcane in Brazil has resulted in positive economic, energetic, and environmental indicators, primarily due to a high agro-industrial yield in Brazil, producing an average of $65 \mathrm{t} / \mathrm{h}$ (NOVA CANA, w.d.), high value when compared with other sources of biofuels such as from: Corn (7.02 t/ha) and Soybean (3t/ha) (As presented by Gusmão et al., 2014), the recycling of by-products, and bagasse utilization for power generation (Capaz et al., 2013). One of the wastes of ethanol production that has great energetic potential is vinasse, which has great importance due to its pollution potential and its generated volume. Almança (1994) defines vinasse as the main liquid waste that is produced when distilling brandy and by autonomous alcohol distilleries and distilleries attached to sugar mills, where it is made for the separation of the fermented mash from ethanol. Vinasse is an aqueous suspension of solid organic and mineral compounds and contains wine that is not entrained during the distillation stage, in addition to residual amounts of sugar alcohol and heavier volatiles.

As stated by Christofoletti et al. (2013), 10-15 L of vinasse are generated during the production of $1 \mathrm{~L}$ of ethanol. Another problem associated with vinasse is the volume produced, which makes its transportation through pumps and pipes unfeasible, being preferable to transport the vinasse through excavated open channels. The problem with this practice is the emissions associated with this transportation. According to Oliveira et al. (2015), these emissions can reach $455 \mathrm{~g} \mathrm{CO}_{2 \text { eq }}$ per $\mathrm{L}$ of ethanol when considering the Center-South region of Brazil.

Due to the high content of nutrients (high organic load of the effluent - See the typical chemical composition of sugarcane vinasse in Table 1) and the large volume generated, vinasse is usually used for fertirrigation in Brazil. For example, in the state of São Paulo, which contains 55\% of Brazilian ethanol plants, only 8 of

Table 1

Vinasse typical chemical composition. Christofoletti et al. (2013).

\begin{tabular}{ll}
\hline Parameter $^{\text {a }}$ & Typical concentration \\
\hline BOD & $5046 \mathrm{mg} / \mathrm{L}$ \\
Potassium & $2056 \mathrm{mg} / \mathrm{L}$ \\
Sodium & $50.2 \mathrm{mg} / \mathrm{L}$ \\
Calcium & $719 \mathrm{mg} / \mathrm{L}$ \\
Sulfate & $710 \mathrm{mg} / \mathrm{L}$ \\
Magnesium & $237 \mathrm{mg} / \mathrm{L}$ \\
Total Phosporus & $190 \mathrm{mg} / \mathrm{L}$ \\
Hardness & $2493 \mathrm{mg} / \mathrm{L}$ \\
Zn & $1.66 \mathrm{mg} / \mathrm{L}$ \\
\hline
\end{tabular}

a All other components of the vinasse have a typical concentration of less than $0.5 \mathrm{mg} / \mathrm{L}$. the 165 distilleries employ alternative processes, such as anaerobic digestion. Although some benefits of fertirrigation should be considered (e.g., reductions in the use of fresh water and mineral fertilizers), the direct application of vinasse to land can pose a problem, as the low $\mathrm{pH}$ and high concentrations of sulfate and organic matter can affect the structure of the soil and surrounding water bodies and reduce crop yields (Fuess and Garcia, 2014).

Fuess and Garcia (2014) describe the results obtained by the works of Zolin et al. (2011), and Previna and Saravanan (2013), which demonstrate the benefits of soil aeration, microbial activity, and the composition of sugarcane; however, those authors also mention that productivity is only increased for a short time. Considering successive applications of vinasse to the soil, especially when such applications are made without planning, a deterioration of physical and chemical characteristics occurs, resulting in impacts on surface and groundwater bodies. As an example, salinization and soil sodification can occur, leading to structural instability. High organic loads can also occur, which reduce the dissolved oxygen. Finally, excessive fertilization can cause instability in the structure of the soil, as well as the eutrophication of water bodies and the inhibition of germination. In Brazil, the Normative Instruction 25, 2009, of the Secretary of Agricultural Defense (SDA in Portuguese) with the Ministry of Agriculture, Livestock and Food Supply (MAPA in Portuguese) (BRAZIL, 2009) sets out the limits to the application of fertilizers in general on the soil and it can be consulted for the study of the application of vinasse, minimizing the risks to soil abovementioned. A more specific regulation relating to the vinasse to be followed in the São Paulo State consists of the regulation 45, 2015 of the Environmental Company of the State of São Paulo (CETESB, 2015) entitled: "VINASSE - Criteria and procedures for application in agricultural soils".

Vinasse may also contain heavy metals and xenobiotic organic pollutants, such as phenol, methylene chloride, chloroform, and pentachlorophenol (Acharya et al., 2008). According to Soobadar (2017), apart from K, organic matter and N, vinasse may contains heavy metals $(\mathrm{Cu}, \mathrm{Zn}, \mathrm{Ni}, \mathrm{Mn}, \mathrm{Pb})$ but their concentrations are in general negligible and most often the heavy metals are below their detection limits on the atomic absorption spectrophotometer ( $5 \mathrm{mg} / \mathrm{kg}$ for $\mathrm{Cu}, \mathrm{Zn}, \mathrm{Ni}, \mathrm{Pb}$ and $10 \mathrm{mg} / \mathrm{kg}$ for $\mathrm{Mn}$ ). The same conclusion can be obtained by the analysis of the studies of Christofoletti et al. (2013), and Koyama et al. (2016), which list the typical concentrations of heavy metals in the vinasse from cane sugar, showing that when these contaminants are presents they are always at concentrations less than $0.5 \mathrm{mg} / \mathrm{L}$. In this context, it is important to observe the standards of the vinasse application on the soil (as it was above-mentioned concerning to the regulation 45,2015 , of the CETESB, 2015) in order to define the correct rate of its application.

A nobler possible destination for this waste, different from the fertigation, is the conversion of the biogas produced during its anaerobic digestion into energy. Several authors have studied the possibility of energy generating from the anaerobic digestion of the stillage and verified the presence of a large energy potential in this waste (Santos et al., 2011). This practice brings about significant improvements because the high organic load of the waste is reduced, the residue receives treatment, and biogas is produced in large quantities. After treatment, vinasse may also be applied as a fertilizer (Salomon et al., 2011). The anaerobic digestion of the stillage for hydrogen production has been also studied (Fu et al., 2017).

According to Poveda (2014), anaerobic digestion is a process performed by various groups of microorganisms. This process accomplishes the conversion of complex organic compounds into biogas, ammonia, water, and new bacterial cells. This complex biochemical process consists of several sequential reactions, which 
are each associated with a specific bacterial population (Barros, 2013).

As shown by the results of the analysis of the life cycle assessment of Barrera et al. (2016), the anaerobic digestion of stillage for energy production is significantly environmentally better than its treatment in lagoons, recovering up to $46 \%$ the exergy extracted from the natural environment during the process, which demonstrates the importance of this treatment option for the stillage.

Various types of digesters are available that can operate in batch or continuous flow. According to Poveda (2014), the most suitable reactors for use in the ethanol industry have continuous flow, given the large production of vinasse.

As stated by Souza et al. (1992), upflow anaerobic sludge blanket (UASB) reactors are most suitable for vinasse treatment. This technology consists of a tank in which the in natura effluent is injected into the lower part, crossing an upflow sludge blanket that consists of granules of microorganisms. A three-phase separator is present in the upper part, which holds the sludge reactor; then, the biogas is captured, and the treated effluent is withdrawn. According to Rego and Hernandez (2006), UASB reactors seek to overcome previous difficulties because they allow a microbial film (which has upward movement due to gas bubbles) to release gas by acting on a deflector and to return to the bottom of the reactor. This setup gradually increases the ability to operate the reactor with high organic loads and low hydraulic retention times (during which the organic matter to be digested remains). Fig. 1 shows an example of these reactors.

According to NASKEO (2016), the volume ratio of $\mathrm{CH}_{4}$ present in the biogas varies from $50 \%$ to $75 \%$; the remainder consists primarily of carbon dioxide $\left(\mathrm{CO}_{2}\right)$ and traces of other gases, such as hydrogen sulfide $\left(\mathrm{H}_{2} \mathrm{~S}\right)$ and water vapor $\left(\mathrm{H}_{2} \mathrm{O}\right)$. The energy potential of biogas varies depending on the quantity of methane, which determines its calorific value (Salomon and Lora, 2009). The existence of noncombustible material, such as water and carbon dioxide, in the biogas makes its burning process less efficient because these materials absorb part of the energy generated. Moreover, caustic substances reduce the equipment's life and, depending on the application, the biogas must be purified to remove $\mathrm{H}_{2} \mathrm{~S}, \mathrm{CO}_{2}$, and humidity.

There are several applications for biogas: heating the digester itself, as temperature is a limiting factor for the production of biogas, and heating buildings in cold countries (Nuvolari, 2003); use in internal combustion engines to generate electricity; power boilers; use in combined heat and power generation processes (Salomon and Lora, 2009); treated biogas injection into gas grids (whose use is now standard in some European countries, such as Sweden, Switzerland, Germany, France, etc.) (Appels et al., 2008); and vehicular use, such as use in urban bus fleets (Nadaletti et al., 2015). According to Lantz (2012), the new large-scale biogas plants in Sweden are all oriented toward vehicular fuel production. One of the great advantages of the energy use of biogas is that unlike other forms of renewable energy, biogas has no geographical limitations, and the technology required to produce energy from biogas is neither complex nor monopolistic (Taleghani and Kia, 2005).

Based on Environmental Sanitation Technology Company (CETESB, 2006), Santos et al. (2016) presented the basic components for the deployment of a biogas energy recovery plant. These components are listed below:

i) Burner: used for flue gas, which is not used for power generation;

ii) Gasometer: used for storage and gas flow regulation; the gasometer is important for the maintenance of power generation equipment;

iii) Compressor: used to collect gas and pump the gas through the pipe collection;

iv) Treatment Unit: used to remove impurities $\left(\mathrm{H}_{2} \mathrm{~S}, \mathrm{H}_{2} \mathrm{O}\right.$ and siloxanes) and expand the methane content $\left(\mathrm{CH}_{4}\right)$ of biogas, increasing its calorific value and decreasing the risk of problems with the plant equipment;

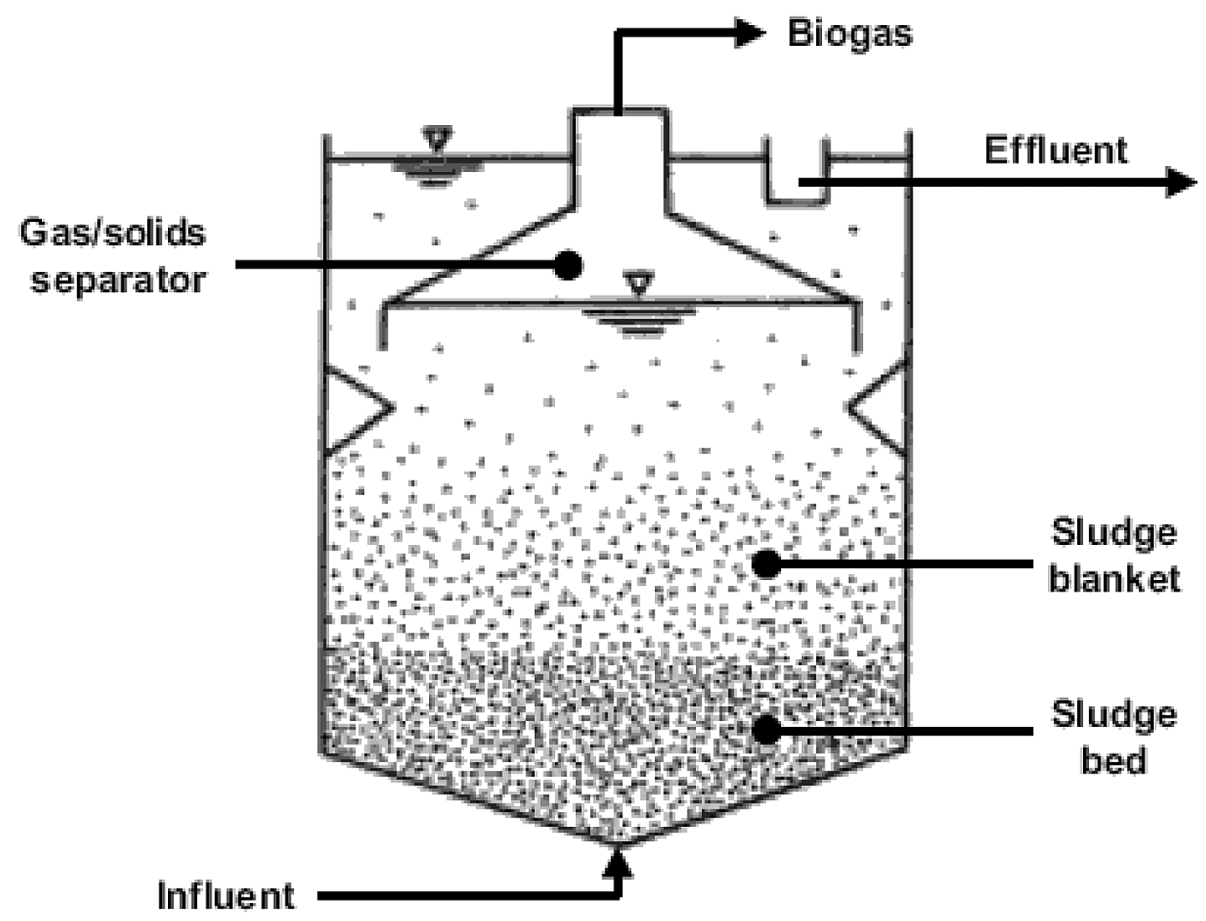

Fig. 1. UASB reactors. Source: Toprak (2013). 
v) Internal Combustion Engine: transforms the chemical energy in the biogas into mechanical energy, working coupled to a generator;

vi) Pipeline: promotes biogas and transport in the system;

vii) UASB reactor: performs the anaerobic digestion of vinasse, generating methane gas.

The implementation costs of the components necessary for the energy use of an alcohol and/or sugar production plant are shown in Table 2. Fig. 2 shows a diagram of a plant for power generation from biogas.

Several authors have studied biogas production from stillage and stressed the advantages of such use. Nogueira et al. (2015) studied the costs of using this waste to generate electricity and obtained variable costs between 38 and 47 USD/MWh. Moreda (2016) analyzed the potential to generate biogas and electricity in Uruguay and obtained a maximum of 2.6 million $\mathrm{m}^{3} / \mathrm{y}$, which is equivalent to an annual power production of $8.9 \mathrm{GWh} / \mathrm{y}$. Zumar et al. (2016) estimated the energy production potential as $124 \mathrm{TJ} \mathrm{e} /$ $\mathrm{y}$ on the island of Mauritius and suggested the digestion of vinasse as an alternative to reduce the heavy dependence of the island on fossil fuels. According to Moraes et al. (2014), the use of biogas from vinasse for power generation in stationary internal combustion engines could generate 85 million USD of carbon credits in revenue for Brazil in 2009.

In this context, to promote the development of the use of vinasse for biogas production and the subsequent generation of electricity, this study evaluates the costs, the financial attractiveness, the potential for economically viable energy production and the reduction of $\mathrm{CO}_{2}$ emissions in Brazil. Economic viability was analyzed in terms of sugarcane planting area, considering autonomous and annexed plants; the sensitivity of this feasibility was also evaluated with regard to several influential parameters. One of the main difficulties for the development of the present study was the collection of reliable and in accordance with the Brazilian reality data related to anaerobic biodigestion of the vinasse, and it was overcome by the bibliographical research. The collected data were used for the calculations of this paper, as shown by the equations presented in the following topic.

\section{Methods}

The methodology of this study is based on the correlation between the sugarcane acreage of a small to large (100-150,000 ha) attached or autonomous plant and the associated vinasse production if all of the cane was processed for the generation of ethanol. From a known planted sugarcane area, it is possible to obtain the mass of sugarcane produced by using the following equation:

Table 2

Implementation costs of the components necessary for the energy use of biogas for an attached or autonomous plant.

\begin{tabular}{ll}
\hline Component & ${\text { Corrected Cost }(2014)^{\mathrm{a}}}^{\mathrm{a}}$ \\
\hline Burner & $97,128 \mathrm{USD} / \mathrm{unit}^{\mathrm{b}}$ \\
Gasometer & $43.7 \mathrm{USD} / \mathrm{m}^{3} \mathrm{~b}$ \\
Compressor & $242.8 \mathrm{USD} /\left(\mathrm{m}^{3} \times \mathrm{h}\right)^{\mathrm{b}}$ \\
Pipeline & $121.4 \mathrm{USD} / \mathrm{m}^{\mathrm{b}}$ \\
UASB Reactor & $170 \mathrm{USD} / \mathrm{m}^{3 \mathrm{c}}$ \\
Internal Combustion Engine & $486 \mathrm{USD} / \mathrm{kW}^{\mathrm{b}}$ \\
\hline
\end{tabular}

${ }^{a}$ Exchange rate adopted: 1 USD $=3.83 \mathrm{BRL}$ (average price from august to january) (ACINH, 2016).

b Source: Obtained from CETESB (2006) and corrected to 2016 by the use of Calculator Citizen of the Central Bank Of Brazil (2016).

c Source: Obtained from SANEPAR (2006) and corrected to 2016 by the use of the Calculator Citizen of the Central Bank Of Brazil (2016).
$T_{c}=A_{c} \times P_{C}$

Where $A_{c}$ is the sugarcane planted area in ha, $P_{c}$ is the productivity in $t$ of sugarcane per hectare $t / h a$, and $T_{c}$ is the mass $(t)$ of sugarcane produced.

For $T_{c}$, it is possible to calculate the volume of vinasse produced by multiplying the mass of sugarcane produced by the specific production of vinasse (Equation (2)). Based on the volume of stillage produced and the typical COD load of that residue, the total COD load of the entire volume of vinasse produced can be calculated (Equation (3)). With the COD produced and the anaerobic reactor efficiency, we have the removed COD (Equation (4)). In this study, Upflow Anaerobic Sludge Blanket Reactors (UASB) were considered operating at ambient mesophilic temperature $\left(32-37{ }^{\circ} \mathrm{C}\right.$ ) for the anaerobic digestion of the vinasse, because several papers found in the literature indicate these reactors for the stillage treatment (Souza et al., 1992) by allowing obtaining greater efficiencies in this temperature range (Moraes et al., 2015).

Then, the methane flow generated by the anaerobic degradation of vinasse is obtained by multiplying the removed COD load by the methane production rate per unit of COD removed (Equation (5)). In the present work, the treatment of vinasse in a UASB reactor at a mesophilic temperature was considered.

$V_{v}=P_{v} \times T_{C}$

$C O D_{\text {total }}=V_{v} \times C O D_{\text {typical }}$

$C O D_{\text {rem }}=C O D_{\text {total }} \times E_{f}$

$Q_{C H 4}=C O D_{\text {rem }} \times f_{p}$

Where $\mathrm{V}_{\mathrm{v}}=$ volume of vinasse in $\mathrm{m}^{3} / \mathrm{y}, \mathrm{P}_{\mathrm{v}}=$ vinasse production factor per $\mathrm{t}$ of milled sugarcane $\mathrm{m}^{3} / \mathrm{t}, \mathrm{COD}_{\text {typical }}=$ typical vinasse COD in $\mathrm{kg} / \mathrm{m}^{3}, \mathrm{COD}_{\text {total }}=$ total COD load of the entire vinasse volume in $\mathrm{kg}, \mathrm{COD}_{\mathrm{rem}}=\mathrm{COD}$ removed during vinasse treatment in $\mathrm{kg}$, $E_{f}=$ anaerobic reactor efficiency, $f_{p}=$ methane production factor in $\mathrm{m}^{3}$ per $\mathrm{kg}$ of COD removed and $\mathrm{Q}_{\mathrm{CH} 4}=$ methane flow in $\mathrm{m}^{3} / \mathrm{y}$.

Using the methane flow, the power and the energy generated in the process (which is defined as the power generated multiplied by the operation time) are calculated by using equations (6) and (7).

$$
\begin{aligned}
& P=\frac{Q_{C H 4} \times \eta \times L C V_{C H 4}}{31.546 \times 10^{6}} \\
& E_{\text {year }}=\frac{P \times \Delta t}{10^{6}}
\end{aligned}
$$

Where $\eta$ is the efficiency or performance of the internal combustion engine; $\mathrm{LCV}_{\mathrm{CH} 4}$ is the Lower Calorific Value of methane in $\mathrm{J} / \mathrm{m}^{3}$; $31.546 \times 10^{6}$ is a correction factor of $\mathrm{Q}_{\mathrm{CH} 4}$ from $\mathrm{m}^{3} / \mathrm{y}$ to $\mathrm{m}^{3} / \mathrm{s}$; $\mathrm{E}_{\text {year }}$ is the energy generated in $\mathrm{MWh} / \mathrm{y} ; \mathrm{P}$ is the power generated in $\mathrm{W} ; 10^{6}$ is a factor for conversion of $\mathrm{P}$ from $\mathrm{W}$ to $\mathrm{MW}$ and $\Delta t$ is the operating time of the plant in $\mathrm{h} / \mathrm{y}$.

Knowing that the combustion of $\mathrm{CH}_{4}$-which generates biogenic $\mathrm{CO}_{2}$ and can be considered to be a clean and neutral emission-and its subsequent conversion into electrical energy and injection into the national grid of electrical energy makes it an economy in the generation of some other source in the country, it is possible to calculate the avoided emissions in $\mathrm{t}$ of $\mathrm{CO}_{2}$ using equation (8). The product of the avoided emissions (Equation (8)) and the value of carbon credits also allows the calculation of the carbon credits that can be obtained due to electricity generation through biogas, as follows: 


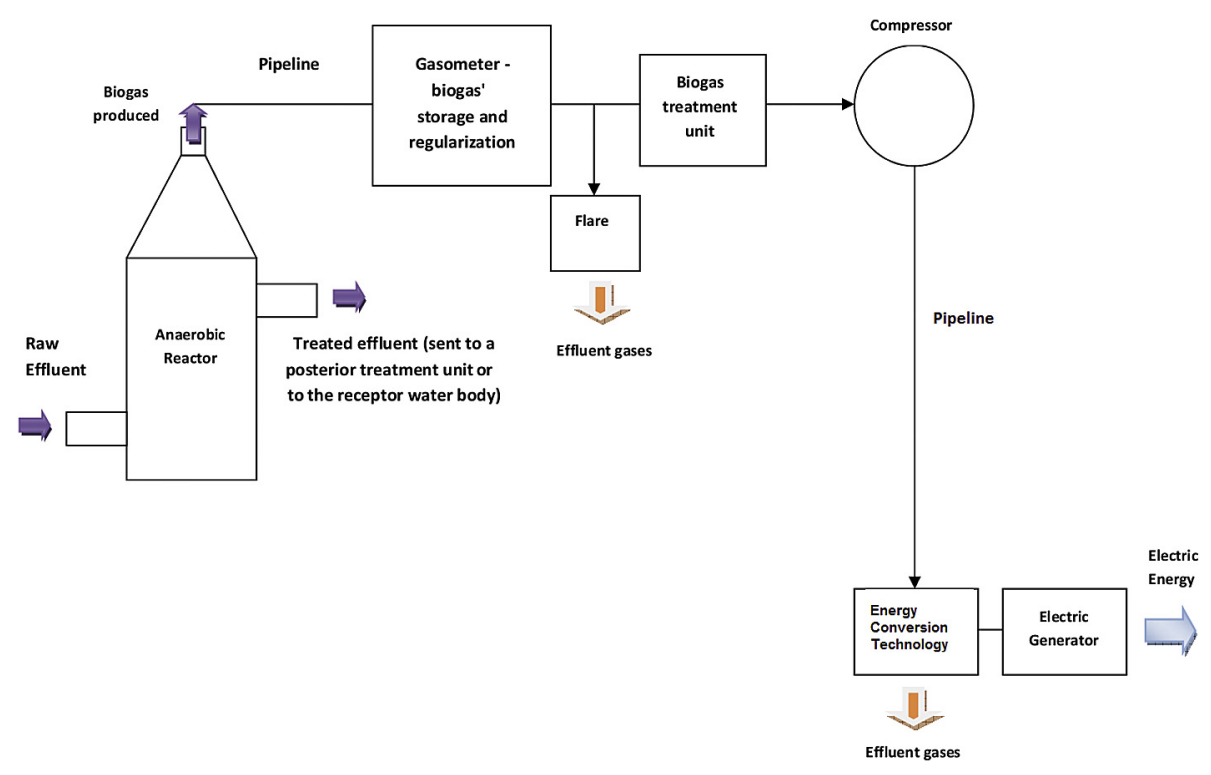

Fig. 2. Scheme of a biogas electricity generation plant. Source: Santos et al. (2016).

$E_{a v}=F_{\text {emission }} \times E_{\text {year }}$

Where $\mathrm{F}_{\text {emission }}=$ the emission factor of the Brazilian electricity grid in $\mathrm{tCO}_{2 \text { eq }} / \mathrm{MWh}$ and $\mathrm{E}_{\mathrm{av}}=$ the annual avoided $\mathrm{CO}_{2}$ emissions in $\mathrm{tCO}_{2 \mathrm{eq}} / \mathrm{y}$.

For the project feasibility analysis, it is necessary to consider the initial investment made. The initial investment is the sum of the individual costs of the plant components, as shown in equations (9) and (10).

$I_{\text {total }}=\sum$ Individual Costs

$$
\begin{aligned}
I_{\text {total }}= & \text { Cost }_{\text {cec }}+\text { Cost }_{\text {gas }}+\text { Cost }_{\text {burn }}+\text { Cost }_{\text {comp }} \operatorname{Cost}_{\text {transp }} \\
& +\operatorname{Cost}_{\text {Reactor }}
\end{aligned}
$$

Where $\mathrm{I}_{\text {total }}=$ the initial investment in USD, Cost $\mathrm{cec}_{\mathrm{c}}$ is the cost of the energy conversion component in USD; Cost $_{\text {gas }}$ is the cost of the gasometer in USD; Cost burn $_{\text {is }}$ ise cost of the burner in USD; Costcomp is the cost of the compressor in USD; Cost $_{\text {Reactor }}$ is the cost of

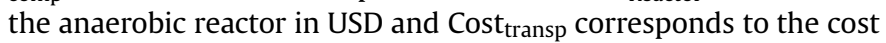
of the pipeline for gas transportation in USD.

Maintenance costs are also required to verify the fixed economic viability of the project and are calculated based on the sum of the fixed $\left(\mathrm{Com}_{\mathrm{f}}\right.$ in USD/y) and variable $\left(\mathrm{Com}_{\mathrm{v}}\right.$ in USD/y) costs of maintenance and operation (Equation (11)).

$\mathrm{Com}=\mathrm{Com}_{f}+\mathrm{Com}_{v}$

Finally, the net present value (NPV in USD), which is a parameter for economic viability analysis, can be calculated for each power that can be installed (Equation (12)). When the NPV is no longer negative and is equal to zero, spending (investment and maintenance costs) and income are balanced when considering the temporal variation of money through the discount rate i. Values greater than zero indicate the economic viability of the enterprise.

$N P V=\sum_{t=1}^{n} \frac{C F(t)}{(1+i)^{t}}-I$

Where $C F(t)$ is the cash flow in each year in USD/y, which is given by the difference between revenues and expenses, $t$ is the current year and $n$ is the biogas plant lifespan in years.

To estimate the energy production of vinasse, it was necessary to identify the variables described in equations (1)-(12), which are presented in Table 3. The results were obtained for annexed and autonomous distilleries, considering an internal combustion engine as the energy conversion technology. We also considered that ten percent of the energy production will be consumed in heating the anaerobic reactors, and the adopted collection tube length was $750 \mathrm{~m}$. As reported by Santos et al. (2016), the gasometer was sized for a retention time of two days $(48 \mathrm{~h}$ ) for the biogas flow, the costs of only one burner were included in the analysis and the lifetime adopted for the internal combustion engine was $8 \mathrm{y}$. The entire plant lifespan was adopted as $15 \mathrm{y}$, which implies the purchase of a new cycle Otto engine in the eighth year.

By means of the presented equations (Equations (1)-(12)), it was possible to establish a linear relation between the NPV (Equation (12)) and the sugarcane planted area $\left(A_{c}\right)$, using the software Microsoft Excel ${ }^{\circledR}$, that allowed the determination of the minimum economically viable planted sugarcane area $\left(A_{\min }\right.$, obtained when NPV $=0$ ) that should be used by a plant for ethanol generation, generating an enough volume of vinasse to produce a discharge of biogas that will allow the economic feasibility of its energy use. This minimum value of the viable area $\left(A_{\min }\right)$ enabled the calculation of the minimum viable milled sugarcane mass ( $\mathrm{T}_{\mathrm{cmin}}$, by Equation (1)). These data were then used to evaluate the economically feasible energy potential of the biogas produced by vinasse in Brazil.

This potential assessment was performed by an analysis of a sample of cities and their sugarcane plantation areas, according to data from National Institute for Space Research (INPE, 2013). Thirtyfive cities were analyzed in several states and planting areas that ranged from small to large (minimum area of approximately 500 ha and maximum area of approximately 97,000 ha). A procedure was then used that is similar to the procedure applied to flow duration curves for hydroelectric plants (described in Souza et al., 2009): the area values were arranged in descending order, and the percentage of occurrence of each area among the total number of collected areas was then calculated, which can be used to represent the probability of being overcome among the growing area in the country $(P)$.

When the minimum necessary areas of cultivation for viable autonomous and attached plants are interchanged in this curve, it is 
Table 3

Parameters used in the analysis.

\begin{tabular}{|c|c|c|}
\hline Parameter & Value & Source \\
\hline Vinasse production (relative to the volume of ethanol) & 10 a $15 \mathrm{~m}^{3} / \mathrm{m}^{3}$ ethanol & Christofoletti et al. (2013) \\
\hline Vinasse production in $L / t$ of processed cane $P_{v}$ & $\begin{array}{l}156 \mathrm{~L} / \mathrm{t} \text { in annexed distilleries (alcohol and sugar) } \\
910 \mathrm{~L} / \mathrm{t} \text { in autonomous distilleries (only alcohol) }\end{array}$ & Lora $(2000)$ \\
\hline $\begin{array}{l}\text { Average productivity of sugarcane per } \\
\text { unit area planted in Brazil } \mathrm{P}_{\mathrm{c}}\end{array}$ & $65 \mathrm{t} / \mathrm{ha}$ & NOVA CANA (w.d.) \\
\hline Methane production factor $\mathrm{f}_{\mathrm{p}}$ & $0.33 \mathrm{~L} / \mathrm{gDQO}_{\text {removed }}$ & Granato and Silva (2002) and Santos et al. (2011) \\
\hline Medium COD of vinasse of annexed plants & $37.5 \mathrm{~kg} / \mathrm{m}^{3}$ & Santos et al. (2011) \\
\hline Medium COD of vinasse of autonomous plants & $21.0 \mathrm{~kg} / \mathrm{m}^{3}$ & Bonomi et al. (2012) apud Moraes et al. (2014). \\
\hline Removal efficiency of COD $E_{f}$ & $74 \%$ a & Moraes et al. (2015) \\
\hline Performance of the internal combustion engine $\eta$ & $33 \%$ & CETESB (2006) \\
\hline Percentage of methane in biogas & $60 \%$ & AEBIOM (2009) \\
\hline Methane Lower Calorific Value $\mathrm{LCV}_{\mathrm{CH} 4}$ & $35.5 \mathrm{MJ} / \mathrm{m}^{3}$ & Qasin (1999) \\
\hline Hours per year of electricity generation $\Delta t$ & $8200 \mathrm{~h}$ & Adopted \\
\hline Energy sale rate $\mathrm{T}$ & 72.6 USD/MWh & ANEEL (2015). \\
\hline Discount rate i & 0.12 & Adopted \\
\hline Operation and maintenance costs & $\begin{array}{l}\text { Fix }^{\mathrm{b}}-3.5 \% \text { of the initial investment } \\
\text { Variable }^{\mathrm{c}, \mathrm{d}}-4.2 \mathrm{USD} / \mathrm{MWh}\end{array}$ & IRENA (2012) \\
\hline Average $\mathrm{CO}_{2}$ emission factor (Brazil) ${ }^{\mathrm{e}}$ & 0.5836 & MCT (2014). \\
\hline Hydraulic retention time in the UASB reactor & $19.92 \mathrm{~h}$ & Moraes et al. (2015) \\
\hline Cost of carbon credit & $0.5 \mathrm{USD} / \mathrm{tCO}_{2}$ & ECX (2013) apud Leme et al. (2014). \\
\hline
\end{tabular}

a Average efficiency values of mesophilic UASB raised by Moraes et al. (2015).

b Consist of labour, scheduled maintenance, routine component/equipment replacement, insurance, etc.

c Include costs as: ash disposal, unplanned maintenance, non-biomass fuels costs, equipment replacement and incremental servicing costs.

d Typical cost of anaerobic digestion systems operation - IRENA (2012).

e Emission factor of the Brazilian interconnected system for CDM purposes, calculated by the order of analysis method.

possible to find the probability that the minimum area of each type of plant will be overcome. This result was multiplied by the total area of cane planted in Brazil to obtain the area of cane planted in the country in which it would be possible to use of stillage for biogas production, in a such a way that, this could be applied to equations (1)-(8), being obtained by the end of the potential energy and $\mathrm{CO}_{2}$ emissions avoided are economically viable in the country.

\section{Results \& discussion}

\subsection{Energy production, avoided emissions and economic viability}

Table 4 shows the different areas utilized for the calculations, in addition to the sugarcane mass, the vinasse volume, and the methane volumetric flow obtained for annexed and autonomous distilleries, by using equations (1), (3) and (5). Using the methane volumetric flow, equations (6)-(12) could then be applied for the energetic, environmental and economic parameter calculation (Table 5).

Using the results presented in Table 5, an evaluation of the economic feasibility of the recovery can be performed using equation (12). The correlation between the NPV and the planting area is shown in Fig. 3. Considering the temporal variation of money, the minimum area that the sugar cane crop must possess for the assurance of biogas power plant economic feasibility (and the equivalent sugarcane mass liable to be produced in this area) occur when the NPV is equal to 0 (i.e., larger areas represent greater viability for the project). These results are presented in Fig. 5 for both types of plants.

Table 4

Planting area, sugarcane mass, vinasse volume and methane flow values obtained for attached and autonomous plants.

\begin{tabular}{|c|c|c|c|c|c|}
\hline \multirow[t]{2}{*}{ Plantation area $A_{c}$ ha } & \multirow[t]{2}{*}{ Sugarcane mass $\mathrm{T}_{\mathrm{c}} \mathrm{kt}$} & \multicolumn{2}{|c|}{ Volume of vinasse $V_{v} 10^{3} \mathrm{~m}^{3} / \mathrm{y}$} & \multicolumn{2}{|c|}{ Methane flow $\mathrm{Q}_{\mathrm{CH} 4} 10^{3} \mathrm{~m}^{3} / \mathrm{y}$} \\
\hline & & Annexed plant & Autonomous plant & Annexed plant & Autonomous plant \\
\hline 100 & 6.50 & 1.01 & 5.92 & 9.31 & 30.40 \\
\hline 200 & 13.00 & 2.03 & 11.84 & 18.60 & 60.80 \\
\hline 300 & 20.00 & 3.04 & 17.74 & 27.90 & 91.20 \\
\hline 400 & 26.00 & 4.06 & 23.79 & 37.20 & 121.61 \\
\hline 500 & 33.00 & 5.07 & 29.60 & 46.50 & 152.01 \\
\hline 1000 & 65.00 & 10.10 & 59.20 & 93.10 & 304.02 \\
\hline 2000 & 130.00 & 20.30 & 118.00 & 186.00 & 608.03 \\
\hline 3000 & 195.00 & 30.40 & 177.00 & 279.00 & 912.05 \\
\hline 4000 & 260.00 & 40.60 & 237.00 & 372.00 & 1216.06 \\
\hline 5000 & 325.00 & 50.70 & 296.00 & 465.00 & 1520.08 \\
\hline 10,000 & 650.00 & 101.00 & 592.00 & 931.00 & 3040.16 \\
\hline 20,000 & 1300.00 & 203.00 & 1180.00 & 1860.00 & 6080.32 \\
\hline 30,000 & 1950.00 & 304.00 & 1770.00 & 2790.00 & 9120.49 \\
\hline 40,000 & 2600.00 & 406.00 & 2370.00 & 3720.00 & $12,160.65$ \\
\hline 50,000 & 3250.00 & 507.00 & 2960.00 & 4650.00 & $15,200.81$ \\
\hline 60,000 & 3900.00 & 608.00 & 3550.00 & 5580.00 & $18,240.97$ \\
\hline 70,000 & 4550.00 & 710.00 & 4140.00 & 6519.00 & $21,281.13$ \\
\hline 80,000 & 5200.00 & 811.00 & 4730.00 & 7450.00 & $24,321.30$ \\
\hline 90,000 & 5850.00 & 913.00 & 5320.00 & 8380.00 & $27,361.46$ \\
\hline 100,000 & 6500.00 & 1010.00 & 5920.00 & 9310.00 & $30,401.62$ \\
\hline 150,000 & 9750.00 & 1520.00 & 8870.00 & $14,000.00$ & $45,602.43$ \\
\hline
\end{tabular}


Table 5

Results obtained as a function of the planted area to be processed in the distillery.

\begin{tabular}{|c|c|c|c|c|c|c|c|c|}
\hline \multirow{2}{*}{$\begin{array}{l}\text { Plantation } \\
\text { Area }\end{array}$} & \multicolumn{4}{|c|}{ Annexed Plant } & \multicolumn{4}{|c|}{ Autonomous Plant } \\
\hline & $\begin{array}{l}\text { Generated } \\
\text { Power kW }\end{array}$ & $\begin{array}{l}\text { Available } \\
\text { Energy GWh }\end{array}$ & $\begin{array}{l}\text { Investment } \\
\text { I } 10^{6} \text { USD }\end{array}$ & $\begin{array}{l}\text { Avoided } \\
\text { emissions } \\
\text { kt } \mathrm{CO}_{2}\end{array}$ & $\begin{array}{l}\text { Generated } \\
\text { Power kW }\end{array}$ & $\begin{array}{l}\text { Available } \\
\text { Energy GWh }\end{array}$ & $\begin{array}{l}\text { Investment } \\
\text { I } 10^{6} \text { USD }\end{array}$ & $\begin{array}{l}\text { Avoided } \\
\text { Emissions } \\
\text { kt } \mathrm{CO}_{2}\end{array}$ \\
\hline 100 & 2.73 & 0.020 & 0.194 & 0.01 & 8.91 & 0.066 & 0.271 & 0.04 \\
\hline 200 & 5.45 & 0.040 & 0.200 & 0.02 & 17.82 & 0.131 & 0.297 & 0.08 \\
\hline 300 & 8.18 & 0.060 & 0.206 & 0.04 & 26.72 & 0.197 & 0.323 & 0.12 \\
\hline 400 & 10.91 & 0.080 & 0.212 & 0.05 & 35.63 & 0.263 & 0.349 & 0.15 \\
\hline 500 & 13.63 & 0.101 & 0.217 & 0.06 & 44.54 & 0.329 & 0.376 & 0.19 \\
\hline 1000 & 27.27 & 0.201 & 0.247 & 0.07 & 89.08 & 0.657 & 0.507 & 0.23 \\
\hline 2000 & 54.54 & 0.402 & 0.305 & 0.08 & 178.15 & 1.315 & 0.769 & 0.27 \\
\hline 3000 & 81.80 & 0.604 & 0.364 & 0.09 & 267.23 & 1.972 & 1.031 & 0.31 \\
\hline 4000 & 109.07 & 0.805 & 0.423 & 0.11 & 356.31 & 2.630 & 1.293 & 0.35 \\
\hline 5000 & 136.34 & 1.006 & 0.481 & 0.12 & 445.38 & 3.287 & 1.554 & 0.38 \\
\hline 10,000 & 272.68 & 2.012 & 0.774 & 0.18 & 890.76 & 6.574 & 2.864 & 0.58 \\
\hline 20,000 & 545.37 & 4.025 & 1.360 & 0.23 & 1781.53 & 13.148 & 5.484 & 0.77 \\
\hline 30,000 & 818.05 & 6.037 & 1.946 & 0.29 & 2672.29 & 19.721 & 8.104 & 0.96 \\
\hline 40,000 & 1090.73 & 8.050 & 2.533 & 0.35 & 3563.05 & 26.295 & 10.723 & 1.15 \\
\hline 50,000 & 1363.41 & 10.062 & 3.119 & 0.41 & 4453.81 & 32.869 & 13.343 & 1.34 \\
\hline 60,000 & 1636.10 & 12.074 & 3.705 & 0.47 & 5344.58 & 39.443 & 15.963 & 1.53 \\
\hline 70,000 & 1908.78 & 14.087 & 4.291 & 0.53 & 6235.34 & 46.017 & 18.583 & 1.73 \\
\hline 80,000 & 2181.46 & 16.099 & 4.877 & 0.59 & 7126.10 & 52.591 & 21.202 & 1.92 \\
\hline 90,000 & 2454.14 & 18.112 & 5.463 & 0.70 & 8016.87 & 59.164 & 23.822 & 2.30 \\
\hline 100,000 & 2726.83 & 20.124 & 6.049 & 0.82 & 8907.63 & 65.738 & 26.442 & 2.69 \\
\hline 150,000 & 4090.24 & 30.186 & 8.980 & 0.94 & $13,361.44$ & 98.607 & 39.540 & 3.07 \\
\hline
\end{tabular}

The minimum area of planting for which there is a financial return from the project for an autonomous plant that is much smaller than the area used for an annexed plant because the plant produces less vinasse per $\mathrm{kg}$ of sugarcane (see Table 2).

Fig. 4 shows that the $\mathrm{P} \times \mathrm{A}$ curve can be approximated by a logarithmic curve that obtains a high degree of correlation $\left(R^{2}\right)$. From the analysis of the percentage of occurrence of areas equal to or greater than the cultivated land used in the sample, it is possible to conclude that as greater areas of land are cultivated, it becomes more difficult to overcome these areas. This finding indicates that there are many smaller planting areas in Brazil, with only some areas having larger values. For example, a planting area of 20,000 ha has a $44 \%$ chance of being equaled or exceeded. Larger areas of above 20,000 ha are less likely to be overcome (between 0 and $44 \%$ ).When the minimum necessary areas of cultivation for viable autonomous and attached plants are interchanged in Fig. 4, it is possible to find the probability that the minimum area of each type of plant will be overcome. These results are shown in Fig. 5.

The probability that the minimum feasible area will be overcome is greater when considering autonomous distilleries processing sugar cane for ethanol production (72\%). That is, it is more likely to find cane plantation areas in which the use of vinasse in this type of plant is feasible. However, autonomous power plants represent only $28 \%$ of all sugar mills in Brazil (NOVA CANA, w.d.). These results will be used to estimate the energy potential of economically feasible energy recovery obtained from the anaerobic digestion of vinasse (Section 3.3).

\subsection{Sensitivity analysis}

The economic feasibility of implementing a biogas reuse system depends on the implanted rate, which varies with changes in the

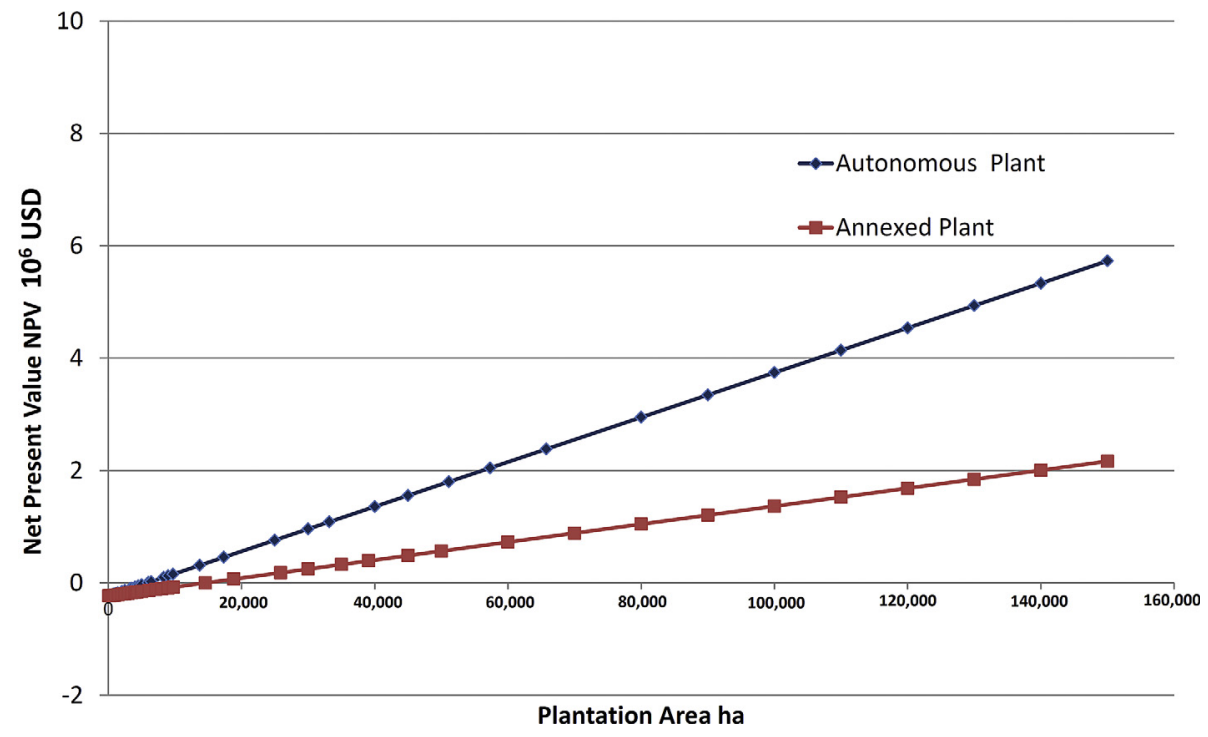

Fig. 3. NPV as a function of the planted sugarcane area. 


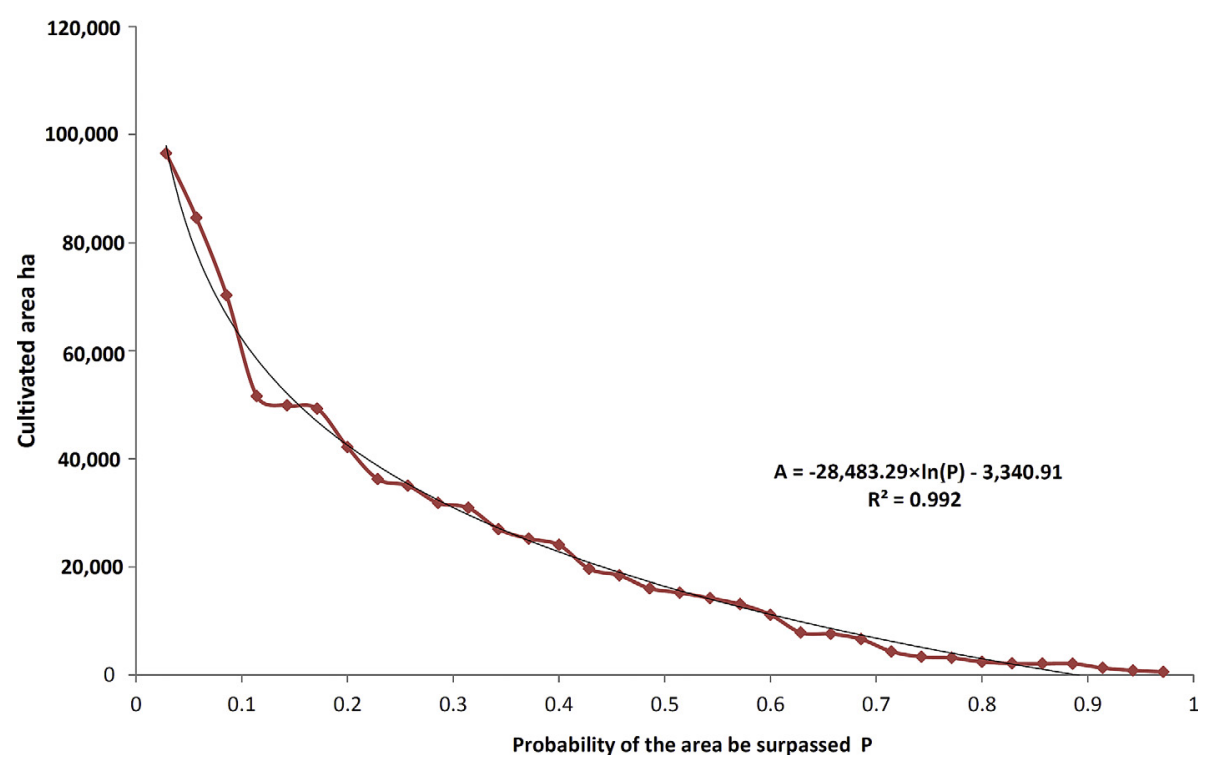

Fig. 4. Cultivated areas and their likelihood of being overcome.

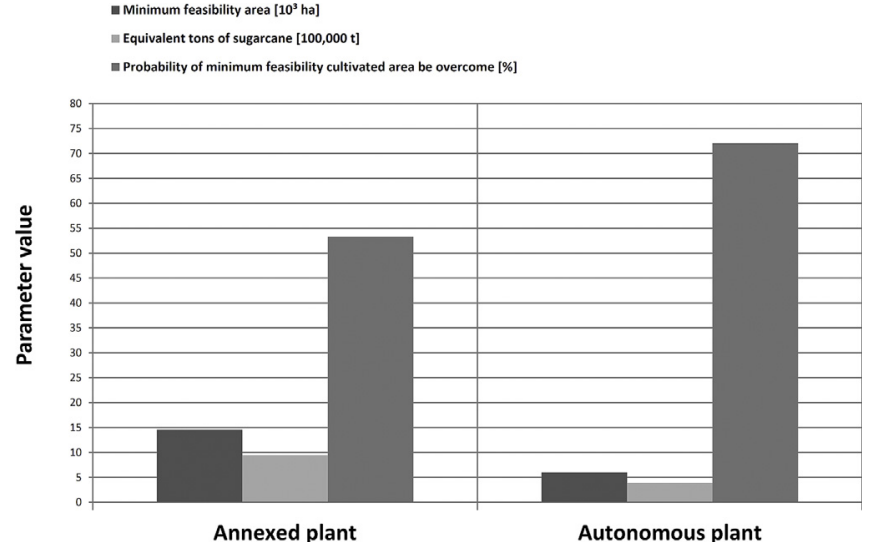

Fig. 5. Minimum areas of economic viability for the energy use of biogas and probability of being overrun. country's economy. It is possible to analyze the variations of the minimum mass of sugarcane to be crushed in order to obtain the economic feasibility of the anaerobic digestion of vinasse for energy in different economic situations (different rates, costs, and discount rates) by means of a sensitivity analysis.

Fig. 6 illustrates a rate of variation between 65 USD/MWh (pessimistic scenario) and $85 \mathrm{USD} / \mathrm{MWh}$ (optimistic scenario). Fig. 7 shows the variation of the minimum mass of sugarcane $t$ as a function of the percentage change from the initial investment and development. Finally, Fig. 8 shows the sensitivity of the minimum mass of sugar amidst different discount rate variations.

Fig. 6 shows that the minimum mass of milled cane that makes the enterprise economically feasible (NPV $>0)$ experiences greater fluctuations for annexed plants. This difference occurs because the annexed plants produce sugar in addition to alcohol, generates less stillage and more sugarcane should be milled to compensate for the low fare, culminating in a larger minimum mass of sugarcane.

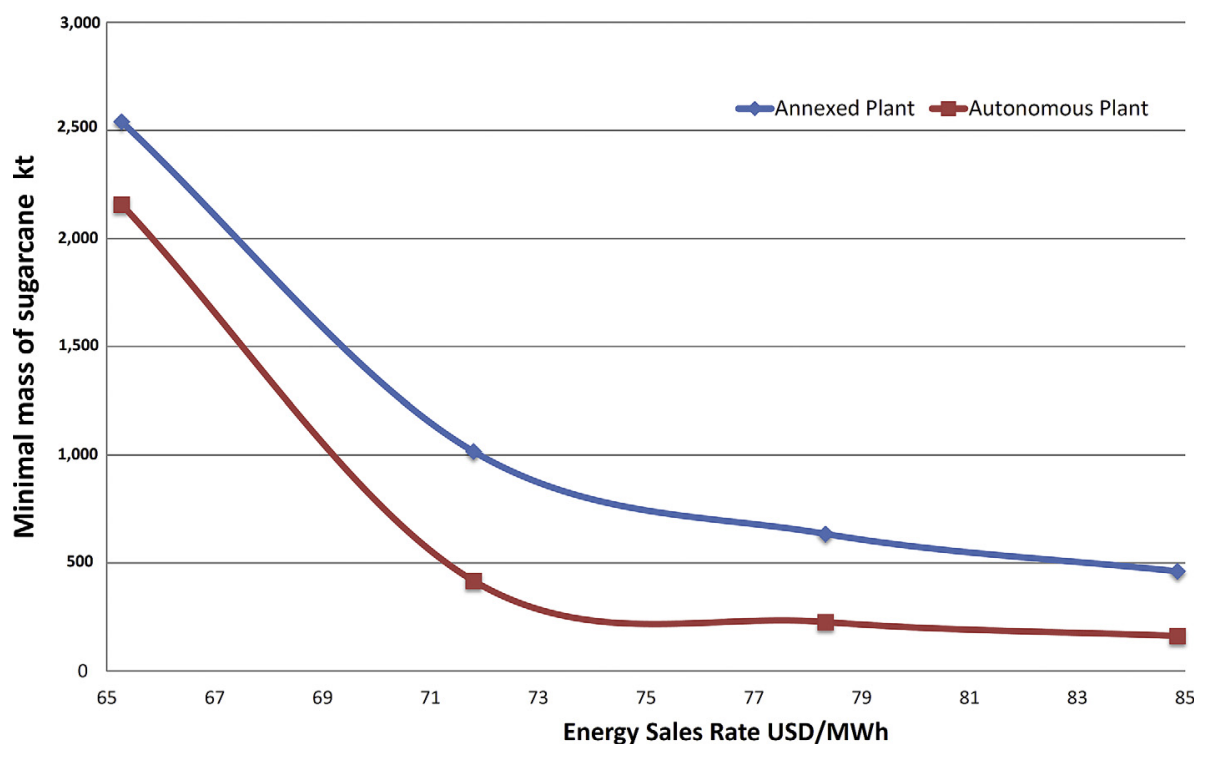

Fig. 6. Minimum mass of milled cane as a function of the tariff. 


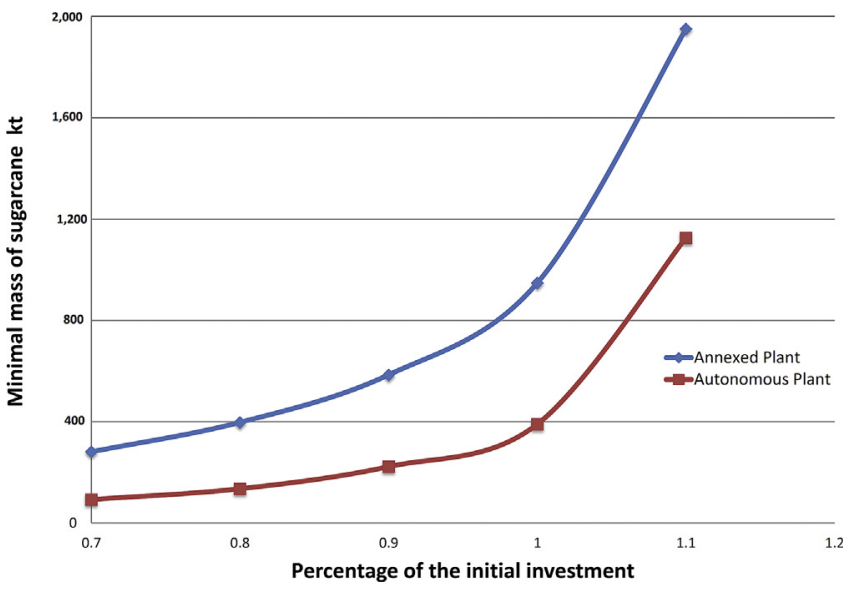

Fig. 7. Relation between total costs and the minimum mass of milled cane.

Moreover, the minimum mass decreases according to the rate that values increase.

Fig. 6 also shows the high impact of energy sale rates at the minimum mass of milled sugarcane, as this value decreases more than $80 \%$, varying from 2540 to $461 \mathrm{kt}$, with an increase of 20 USD/ MWh in the case of annexed plants. Fig. 6 shows that when the initial investment decreases, the plant will need to grind a small mass of sugarcane to achieve financial feasibility for energy generation from vinasse biogas (smaller minimum mass of milled sugarcane).

Fig. 8 shows that a greater discount rate will generate more interest in the investment; then, it will be necessary to grind a greater mass of sugarcane to make the enterprise economically feasible. Figs. 6-8 show that the factor with the greatest impact on the economic viability was the energy sale rate, while changes in investment exerted a smaller effect on the results.

\subsection{Potential estimates}

Based on the previous results (Table 5), we can obtain the index of energy production and the avoided emissions in terms of the mass of milled sugarcane for annexed and autonomous plants. In annexed plants, the vinasse produced due to sugarcane processing allows the recovery of $3.05 \mathrm{kWh}$ and the avoidance of $1.81 \mathrm{kgCO}_{2}$ per $t$ of milled sugarcane. In the case of autonomous plants, these values will be $10.11 \mathrm{kWh} / \mathrm{t}$ and $5.9 \mathrm{kgCO}_{2} / \mathrm{t}$.

Using these values, the mass of sugarcane produced in 2013/ 2014 in Brazil and the percentages of annexed and autonomous plants in Brazil (presented above) and considering that the milled sugarcane mass for these plants is distributed with the same percentages as the plant type distribution (quoted previously), it was possible to estimate the energy production potential and the avoided emissions for both types of plants and for the whole country (Table 6). Then, the economically feasible potential was estimated by calculating the product of the energetic potential and the probability of overcoming the minimum area for each plant type (as presented in Fig. 5).

Fig. 9 presents a sensitivity analysis of the energy potential as a function of the percentage of produced sugarcane that is sent to autonomous plants (where the vinasse production is higher). The analysis shows that a variation of $10 \%$ in the sugarcane sent to autonomous plants implies an energy potential elevation of $0.44 \mathrm{TWh}$ and an avoided emissions potential of $0.26 \mathrm{MtCO}_{2}$. However, the number of autonomous plants is decreasing. In 1990, $48 \%$ of the distilleries in Brazil were autonomous, and $44.8 \%$ of the distilleries were annexed. In 2007, as mentioned above, these values changed to 28 and $68 \%$.

Table 6 shows that the energy potential generated by autonomous plants is much greater than that generated by annexed plants. This difference could be explained by the higher production of alcohol and vinasse in these plants (for the same harvest areas), which also results in greater economic profitability. The emissions avoided due to the economy of the grid's electricity consumption also follow this trend (i.e., the avoided emissions are much greater for autonomous plants than for annexed plants).

According to National Energy Balance (2014), the internal energy supply in the whole country was near 624 TWh. The energy generation from vinasse biogas could reach $0.52 \%$ of the total national energy consumption. In 2014, the total $\mathrm{CO}_{2}$ emissions of the National Industry reached $8.97 \times 10^{7} \mathrm{tCO}_{2}$. The total avoided $\mathrm{CO}_{2}$

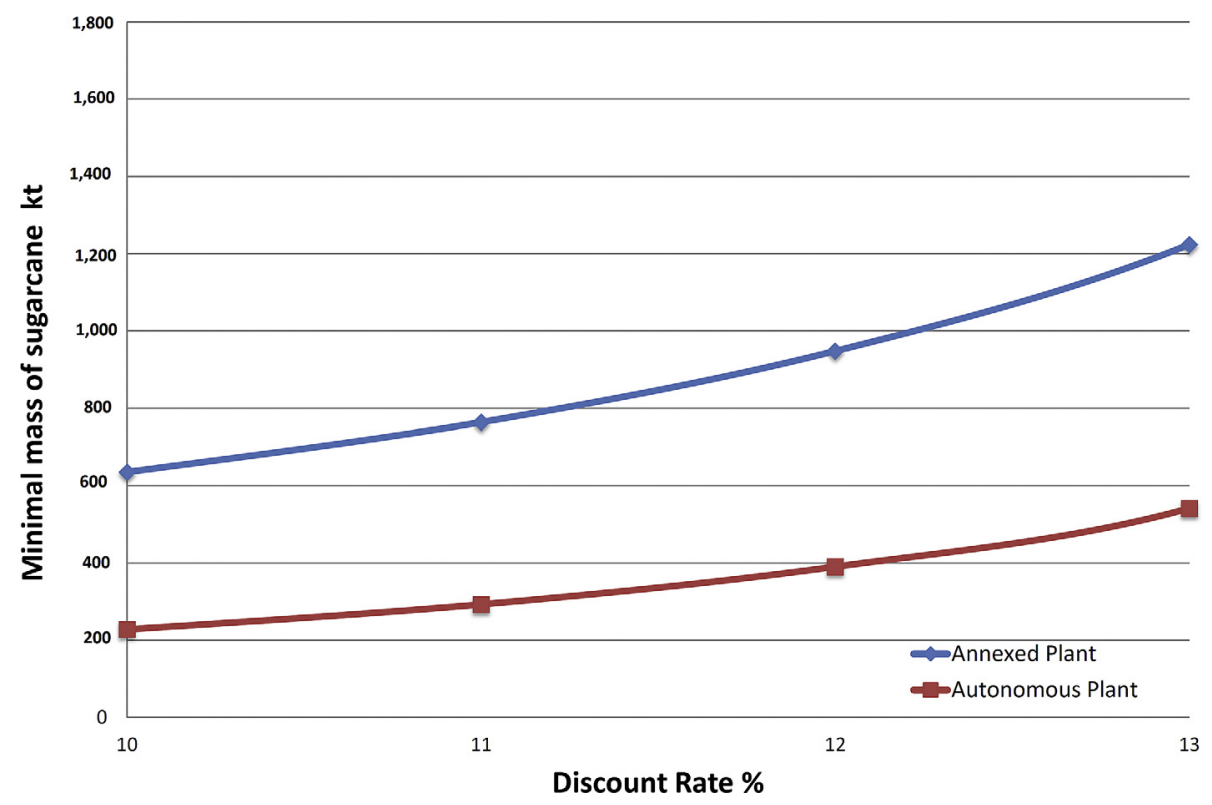

Fig. 8. Minimum mass of milled cane as a function of the discount rate. 
Table 6

Mass of sugarcane produced in Brazil, energy potential, and avoided emissions potential. Source: CONAB (2015) and NOVA CANA (w.d.)

\begin{tabular}{|c|c|c|c|c|c|}
\hline $\begin{array}{l}\text { Tons of sugarcane } \\
\text { planted in Brazil }\end{array}$ & $660 \mathrm{Mt}$ & $\begin{array}{l}\text { Potential Energy of biogas } \\
\text { from vinasse TWh/y }\end{array}$ & $\begin{array}{l}\text { Potential emissions avoided by the } \\
\text { energy using of biogas from } \\
\text { vinasse, } \mathrm{MtCO}_{2} / \mathrm{y}\end{array}$ & $\begin{array}{l}\text { Potential economically } \\
\text { viable energy }{ }^{\mathrm{b}} \mathrm{TWh} / \mathrm{y}\end{array}$ & $\begin{array}{l}\text { Avoided economically } \\
\text { viable emissions }{ }^{c} \mathrm{MtCO}_{2} / \mathrm{y}\end{array}$ \\
\hline $68 \%$ annexed $^{a}$ & $4.48 \times 10^{8}$ & 1.39 & 0.81 & 0.72 & 0.42 \\
\hline $28 \%$ autonomous ${ }^{a}$ & $1.85 \times 10^{8}$ & 1.87 & 1.09 & 1.51 & 0.88 \\
\hline- & $\sum$ & 3.26 & 1.90 & 2.24 & 1.31 \\
\hline
\end{tabular}

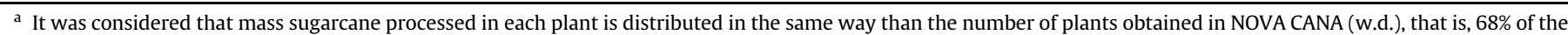
total sugar mass is processed in annexed distilleries and $28 \%$ in autonomous distilleries.

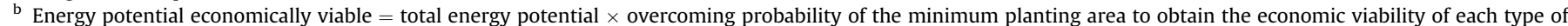
plant (see Table 6).

${ }^{c}$ Avoided emissions of $\mathrm{CO}_{2}$ in case of the economically viable energy potential be explored.

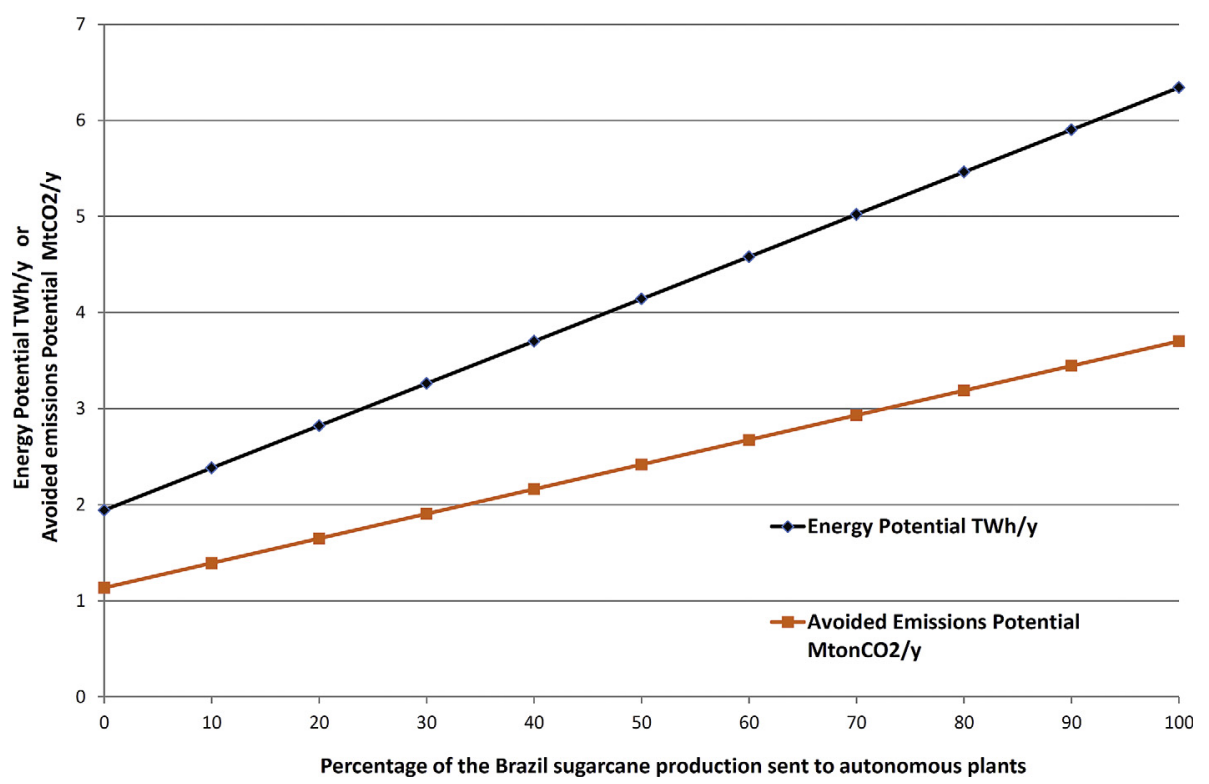

Fig. 9. Sensitivity analysis of the energy potential and avoided emissions potential of the whole country as a function of the autonomous plant percentage.

emissions arising from vinasse biogas could reach more than $2.12 \%$ of this value. Such values are extremely relevant given that we are considering a single type of waste.

By comparing the energy potential from other biogas sources in Brazil (Table 7) with the potential from vinasse biogas (Table 6), we can see that the vinasse, with an economically feasible energy potential of $2.24 \mathrm{TWh}$, has values higher than all other biogas sources in Brazil, except for landfills. In addition, this potential will increase in the future with the expansion of the alcohol industry in Brazil and the associated expansion of sugarcane planting areas.

The Brazilian National Plan about Climatic Change, which was presented in 2008 (MMA, 2008), whose objective is to create internal conditions for addressing the impacts of global change and improving mitigating actions in Brazil, has the following goals, among others: increase cogeneration energy production, especially the cogeneration from sugarcane bagasse, to $11.4 \%$ of the total electricity in the country (in 2030) and increase the internal ethanol consumption by $11 \%$ per year (for the next 10 years). Knowing these goals, which will imply a significant increase in ethanol production and vinasse generation, the inclusion of vinasse energy use in Brazilian energy expansion plans becomes important and strategic.

As estimated by the Brazilian Ministry of the Environment in the National Emissions Inventory (BRAZIL, 2010), agricultural and livestock activities together were responsible for $25 \%$ of Brazilian gross GHG emissions in 2005. This value is due to the constant expansion of utilized areas for these activities, which culminated in the suppression of native forest areas, making the change in land use the main source of GHG emissions in Brazil. In this context, the technology applied in the utilization of vinasse for biogas

Table 7

Brazilian energy potential from several biogas sources.

\begin{tabular}{|c|c|c|c|}
\hline Sources of biogas & Energy Potential & Notes & Reference \\
\hline Landfills & Potential near to $4 \mathrm{TWh}_{\mathrm{e}}$ & The more favorable scenarios for 2030 & Barros et al. (2014). \\
\hline $\begin{array}{l}\text { Sewage treatment in } \\
\text { anaerobic reactors }\end{array}$ & Potential close to $1 \mathrm{TWh}_{\mathrm{e}}$ & $\begin{array}{l}\text { Energy generation in internal } \\
\text { combustion engines }\end{array}$ & Santos et al. (2016) \\
\hline Swine waste & $\begin{array}{l}\text { Production of biogas equal to } 25.10 \times 10^{6} \mathrm{~m}^{3} / \mathrm{y} \text {, } \\
\text { which corresponds to a potential of } 64.4 \mathrm{GWh}_{\mathrm{e}} / \mathrm{y}\end{array}$ & $\begin{array}{l}\text { Energy generation in internal } \\
\text { combustion engines }\end{array}$ & Adapted from Mathias (2014) \\
\hline Hen manure from poultry farms & Potential of $1.277 \mathrm{TWh}_{\mathrm{e}} / \mathrm{y}$ & $\begin{array}{l}\text { Energy generation in internal } \\
\text { combustion engines }\end{array}$ & Ribeiro et al. (2016) \\
\hline
\end{tabular}


production and in electricity generation should be incentivized, so that the environmental benefits that arise from this practice can contribute to minimizing the impact of the use of large planting areas of sugarcane in the generation of alcohol and sugar.

\section{Conclusions}

With the continuous expansion of sugarcane planted areas for the production of alcohol and sugar and the subsequent increase in vinasse generation, as well as the increasingly restrictive standards for waste disposal, the possibility of reusing this byproduct in distilleries for power generation also grows. The present work analyzed the energy generation potential and the economic feasibility of the energy use of biogas produced by the anaerobic digestion of vinasse, from obtained data in studies presented in the literature. Potential analyzes as developed in the present study, which integrate the experimental part of anaerobic digestion of the vinasse for obtaining the basic data used in the calculations may be indicated as a complement to the results presented in this paper. The methodology here developed can also be applied for the potential analysis regarding other regions or other organic waste.

Considering the potential obtained in this study and knowing that the internal ethanol consumption is expected to increase, the strategic inclusion of this waste in Brazilian energy expansion plans becomes relevant. The biogas generated by anaerobic vinasse digestion can also be utilized as vehicular biofuel. This possibility is interesting because the biogas produced can be used for the transport of the sugarcane from harvest to the distilleries in trucks. However, studies that allow for the advancement of biogas treatment technologies and its conversion to biomethane, which is still incipient in Brazil, are necessary.

Ethanol production from sugarcane is an industry of great economic and environmental importance in Brazil. This industry produces a great volume of wastes and consumes a great plantation area but also generates great income and employment for the country. In this context, biogas production from vinasse can undoubtedly contribute to the energy and environmental efficiency of the Brazilian sugar and alcohol industry.

\section{Acknowledgements}

We wish to thank the Coordination for the Improvement of Higher Education Personnel (Coordenação de Aperfeiçoamento de Pessoal de Nivel Superior, CAPES; in Portuguese) for the support given by granting Doctor of Science scholarships to Ivan Felipe Silva dos Santos and to Eruin Ribeiro and a Master of Science scholarship to Andressa Bernal. The authors would like to thank the Brazilian National Council for Scientific and Technological Development (Conselho Nacional de Desenvolvimento Científico e Tecnológico, $\mathrm{CNPq}$; in Portuguese), for granting productivity in research scholarship to Prof. Regina Mambeli Barros (PQ2, Process number: 301986/2015-0).

\section{References}

Acharya, B.K., Mohana, S., Madawmar, D. 2008. Anaerobic treatment of distillery spent wash - a study on upflow anaerobic fixed film bioreactor. Bioresour. Technol. 99, 4621-4626.

ACINH, 2016. Trade, Industry and Services Association of Novo Hamburgo, Campo Bom and Estância Velha. Available at: www.acinh.com.br/servicos/cotacaodolar. Acessed on: 03 May 2017 (In Portuguese).

AEBIOM, October, 2009. A Biogas Road Map for Europe, Ireland. European Biomass Association.

Almança, R., 1994. Assessment of Sugarcane Vinasse Use for Electricity Generation (Case Study). Masters dissertation. PIPGE USP (In Portuguese).

ANEEL, 2015. Brazilian National Electric Energy Agency (Statement about the
Auction of Energy A-5. Available in: www.aneel.gov.br/aplicacoes/noticias/ Output_Noticias.cfm?Identidade1/48528\&id_area Acessed on: 03 May 2017 (In Portuguese).

Appels, L., Baeyens, J., Degrève, J., Dewil, R., 2008. Principles and potential of the anaerobic digestion of waste-activated sludge. Prog. energy Combust. Sci. 34, 755-781.

Barrera, E.L., Rosa, E., Spanjers, H., Romero, O., Meester, S., Dewulf, J., 2016. A comparative assessment of anaerobic digestion power plants as alternative to lagoons for vinasse treatment: life cycle assessment and exergy analysis. J. Clean. Prod. 113, 459-471.

Barros, R.M., 2013. The treaty about solid waste: management, usage, and sus tainability. Rio de Janeiro, Brazil: Interciência; Itajubá, Minas Gerais, Brazil: Acta, p. 376 (In Portuguese).

Barros, R.M., Tiago Filho, G.L., Silva, T.R., 2014. The electric energy potential of landfill biogas in Brazil. Energy Policy 65, 150-164.

BRAZIL, 2009. Normative Instruction Number 25. Secretary of Agricultural Defense (SDA) and Brazilian Ministry of Agriculture, Livestock and Supply (MAPA). Available at: sistemasweb.agricultura.gov.br/sislegis/action/detalhaAto.do? method=recuperarTextoAtoTematicaPortal\&codigoTematica $=1229186$. Acessed on 15 February 2017 (In Portuguese)

BRAZIL. Brazilian Ministry of the Environment., 2010. $2^{\circ}$ National Inventory of Gas Emissions Greenhouse, Brasilia, Brazil (In Portuguese).

BRAZIL, 2015. Economy and Employment. Note: Sugarcane Production Can Reach 654 Millions of Tons. Available at: www.brasil.gov.br/economia-e-emprego/ 2015/04/producao-de-cana-pode-alcancar-654-milhoes-de-toneladas-dizconab. Acessed: 03 May 2017 (In Portugese).

BEN, 2016. Brazilian Energetic Balance. Ministry of Mines and Energy. Available at: ben.epe.gov.br/downloads/S\%C3\%ADntese\%20do\%20Relat\%C3\%B3rio\%20Final_ 2016_Web.pdf. Acessed on: 03 May 2017 (In Portuguese).

BNDES and CGEE, 2008. Brazilian National Bank for Economic and Social Development (BNDES) and the Brazilian Center of Management and Strategic Studies (CGEE). Bioethanol from Sugarcane: Energy for Sustainable Development. BNDES, Rio de Janeiro, Brazil (In Portuguese).

Bonomi, A. Dias, M.O.S, Junqueira, T.L. Cardoso, T.F, Cavalett, O, Franco, H.C. 2012. The Virtual Sugarcane Biorefinery (VSB) - 2011 Report [Internet]. Brazilian Bioethanol Science and Technology Laboratory (CTBE), Technological Assessment Program (PAT), Campinas, p. 128.

Capaz, R.S., Carvalho, V.S.B., Nogueira, L.A.H., 2013. Impact of mechanization and previous burning reduction on GHG emissions of sugarcane harvesting operations in Brazil. Appl. Energy 102, 220-228.

Carvalho, E., 2007. Perspectives on Agroenergy. São Paulo, Brazil: Unica (In Portuguese).

Central Bank Of Brazil, 2016. Citizen Calculator. Available at: www3.bcb.gov.br/ CALCIDADAO/publico/exibirFormCorrecaoValores.do?

method=exibirFormCorrecaoValores\&aba=1. Accessed on: 03 May 2017 (In Portuguese).

CETESB, 2006. Biogas Generation and Use of Energy- Landfill, Version 1.0/CETESB, Department of Environment, the Brazilian Ministry of Science and Technology. São Paulo, Brazil. Environmental Company Of São Paulo State. SMA: CETESB MCT. CD-ROM. Software User's manual v. 1-2, executable programs and source code (In Portuguese).

CETESB, 2015. Environmental Company of São Paulo State. Stillage - Criteria and Procedures for Agricultural Soil Application. 2nd Version. Available at: www. cetesb.sp.gov.br/wp-content/uploads/sites/11/2014/12/DD-045-2015-C.pdf. São Paulo, Brazil. Acessed on: 03/05/2017 (In Portuguese)

Christofoletti, C.A., Escher, J.P., Correia, J.E., Marinho, J.F.U., Fontanetti, C.S., 2013 Sugarcane vinasse: environmental implications of its use. Waste Manag. 33 2752-2761.

CONAB. National Company about Sugarcane Supply. 2015 Crop Surveys. Available at: www.conab.gov.br/conteudos.php? $\mathrm{a}=1253 \&$. Acessed on: 15 February 2016 (In Portuguese)

ECX (European Climate Exchange), 2013. ECX Historical Data Certified Emissions Reduction Futures Contracts ECX Historical Data. Available at: www.ecxeurope com>. Acessed on 03 May 2017.

Fu, S.F., Xu, X.H., Dai, M., Yuan, X.Z., Guo, R.B., 2017. Hydrogen and methane production from vinasse using two-stage anaerobic digestion. Process Saf. Environ. Prot. 107, 81-86.

Fuess, L.T., Garcia, M.L., 2014. Implications of stillage land disposal: a critical review on the impacts of fertirrigation. J. Environ. Manag. 145, 210-229.

FUNDEP, 2016. Research and Development Foundation. Available at: www.fundep. ufmg.br/pagina/2936/especialistas-afirmam-que-brasil-precisa-diversificarsua-matriz-energe-233-tica.aspx. Acessed on: 02/15/2016 (In portuguese)

Granato, E.F., Silva, C.L., 2002. Power Generation from Stillage. an. 4. Meeting about Energy in Rural Areas (In Portuguese).

Gusmão, C., Junior, W., Basso, V.M., 2014. Note: the Profitability of eucalyptus Compared to Other Crops. Available at: www.florestascertificadas.org.br noticias/rentabilidade-do-eucalipto-comparado-outras-culturas. Acessed on 02/15/2017 (In Portuguese).

INPE, 2013. National Institute for Space Research. Monitoring Cane Sugar by Satellite Images. Available at: www.dsr.inpe.br/laf/canasat/cultivo.html. Acessed on 02/15/2015 (In Portuguese).

IRENA, 2012. Biomass for Power Generation. Renewable Energy Technologies: Cost Analysis Series, vol. 1. International Renewable Energy Agency. Available at: www.irena.org/DocumentDownloads/Publications/RE_Technologies_Cost_ Analysis-BIOMASS.pdf. Acessed on: 03 May 2017. 
Koyama, M.H., Araújo Júnior, M.M., Zaiat, M., Ferraz Júnior, A.D.N., 2016. Kinetics of thermophilic acidogenesis of typical Brazilian sugarcane vinasse. Energy 116, 1097-1103.

Lantz, M., 2012. The economic performance of combined heat and power from biogas produced from manure in Sweden - a comparison of different CHP technologies. Appl. Energy 98, 502-511.

Leme, M.M.V., Rocha, M.H., Lora, E.E.S., Venturini, O.J., Lopes, B.M., Ferreira, C.H., 2014. Techno-economic analysis and environmental impact assessment of energy recovery from Municipal Solid Waste (MSW) in Brazil. Resour. Conserv. Recycl. 87, 8-20.

Lora, E.S., 2000. Control of Air Pollution in the Sugar Industry. Federal University of Itajubá (MG), Brazil. Available at: bit.ly/1BUUK1u. Acessed on: 03 May 2017 (In Portuguese).

Mathias, J.C.M., 2014. Manure as a resource: livestock waste management from anaerobic digestion, opportunities and challenges for Brazil. Int. Food Agribus Manag. Rev. 17 (Issue 4).

MCT, 2014. Brazilian Ministry of Science and Technology. Values for Average Emission Factor (published in 2015). Available in: www.mct.gov.br/index.php content/view/354444.html\#ancora. Acessed on 15 June 2015 (In Portuguese).

MMA. Brazilian Ministry of the Environment. National Plan on Climate Change Brasília, 2008. Brasilia, Brazil. Available at: www.mma.gov.br/estruturas/smcq climaticas/_arquivos/plano_nacional_mudanca_clima.pdf. Acessed on 06/15/ 2015 (In Portuguese)

Moraes, B.S., Junqueira, T.L., Pavanello, L.G., Cavalett, O., Mantelatto, P.E., Bonomi, A., Zaiat, M., 2014. Anaerobic digestion of vinasse from sugarcane biorefineries in Brazil from energy, environmental, and economic perspectives: profit or expense? Appl. Energy 113, 825-835.

Moraes, B.S., Zaiat, M., Bonomi, A., 2015. Anaerobic digestion of vinasse from sugarcane ethanol production in Brazil: challenges and perspectives. Renew. Sustain. Energy Rev. 44.

Moreda, I.L., 2016. The potential of biogas production in Uruguay. Renew. Sustain Energy Rev. 54, 1580-1591.

Nadaletti, W.C., Cremonez, P.A., de Souza, S.N.M., Bariccatti, R.A., Belli Filho, P. Secco, D., 2015. Potential use of landfill biogas in urban bus fleet in the Brazilian states: a review. Renew. Sustain. Energy Rev. 41, 277-283.

NASKEO, 2016. Environment Enterprise. Biogas: Renewable Energy Info. Available at: www.biogas-renewable-energy.info/biogas_composition.html. Accessed on: 14 September 2016.

Nogueira, C.E.C., de Souza, S.N.M., Micuanski, V.C., Azevedo, R.L., 2015. Exploring possibilities of energy insertion from vinasse biogas in the energy matrix of Paraná State, Brazil. Renew. Sustain. Energy Rev. 48, 300-305.

NOVA CANA, 2017. Portal with News about the Brazilian Sugar and Alcohol Sector Available at: www.novacana.com/. Acessed on: 03/15/2017 (In Portuguese).

Nuvolari, A., 2003. Sanitary Sewer: Collection, Transport, Treatment and Agricultural Reuse São Paulo, Brazil. Edgard Blücher (In Portuguese).

Oliveira, B.G., Carvalho, J.L.N., Cerri, C.E.P., Cerri, C.C., Feigl, B.J., 2015. Greenhouse gas emissions from sugarcane vinasse transportation by open channel: a case study in Brazil. J. Clean. Prod. 94, 102-107.

Poveda, M.M.R., 2014. Economic and Environmental Analysis of Vinasse Processing with Energy Utilization. Masters Dissertation. São Paulo, Brazil (In Portuguese). Previna, S., Saravanan, A.D., 2013. Ecofriendly utilization of treated distillery effluent (TDE) and inorganic fertilizers management on microbial population and enzymatic activities. IJSRP 3, 1-6.

Qasin, S.R., 1999. Wastewater Treatment Plants - Planninng Design and operation.2.a Ed. Lancaster. USA Technomic Publishing Company, Pennsylvania, USA, p. 1107.

Rego, E.E., Hernandez, F.D.M., 2006. Electricity Anaerobic Digestion of Vinasse from Sugarcane: Technical, Economic and Environmental Contours of an Option. in: Meeting of Energy in Rural Areas 6. Campinas (SP), Brazil (In Portuguese).

Ribeiro, E.M., Barros, R.M., Tiago Filho, G.L., Santos, I.F.S., Sampaio, L.M., Santos, T.V., Braga da Silva, F.G., Silva, A.P.M., Freitas, J.V.R., 2016. Power generation potential in posture aviaries in Brazil in the context of a circular economy. Sustain. Energy Technol. Assess. 18, 153-163.

Salomon, K.R., Lora, E.E.S., Rocha, M.H., del Olmo, O.A., 2011. Cost Calculations for biogas from vinasse biodigestion and its energy utilization. Zuckerind. Berl./ Sugar Ind. Berl. 136, 217-223.

Salomon, K.R., Lora, E.E.S., 2009. Estimate of the electric energy generating potential for different sources of biogas in Brazil. Biomass Bioenergy 33, 1101-1107.

SANEPAR, 2006. Sanitation Company of Paraná, Brazil. UASB, Upflow Anaerobic Sludge Blanket Reactor Reducing Costs and Saving Energy in the Wastewater Treatment. Available at: bit.ly/1QGgghf. Acessed on 03/05/2015 (In Portuguese).

Santos, R.F., Borsoi, A., Secco, D., de Souza, S.M.N., Constanzi, R.N., Brazil's potential for generating electricity from biogas from stillage, World Renewable Energy Congress - Sweden 8-13 May, 2011 Linköping, Sweden, pp. 425-433.

Santos, I.F.S., Barros, R.M., Tiago Filho, G.L., 2016. Electricity generation from biogas of anaerobic wastewater treatment plants in Brazil: an Assessment of Feasibility and Potential. J. Clean. Prod. 126, 504-514.

Soobadar, A., 2017. Application of Vinasse to Sugarcane. Nova Publishers: Sugarcane production, consumption and agricultural management systems chapter, pp. 331-360. Available at: www.novapublishers.com/catalog/product_info. php?products_id=52167. Acessed on 03 May 2017.

Souza, M.E., Fuzaro, G., Polegato, A.R., 1992. Thermophilic anaerobic digestion of vinasse in pilot plant UASB reactor. Water Sci. Technol. 25, 213-222.

Souza, Z., Moreira, A.H., Costa, E.B., 2009. Hydropower: Implementation and Commissioning. Rio de Janeiro (RJ), Brazil, 2a ed. Publishing Company: Interciência (In Portuguese).

Taleghani, G., Kia, A.S., 2005. Technical - economical analysis of the Saveh biogas power plant. Renew. Energy 30, 441-446.

Toprak, H., 2013. Vegetated Submerged Beds and Other High-specific-surface Anaerobic Reactors. Home page hostered by Dokuz Eylul University, Turkey. Available in. web.deu.edu.tr/atiksu/ana58/vege.html. Acessed on: 31 May 2013.

Zolin, C.A., Paulino, J., Bertonha, A., Freitas, P.S.L., Folegatti, M.V., 2011. Exploratory study of the use of vinasse over time. I: soil Characteristics. Agric. Eng. 15, 22-28 (In Portuguese).

Zumar, M.A.B., Mauthoor, S., Mohee, R., 2016. Potential of biogas production from biomass and waste materials in the Small Island Developing State of Mauritius. Renew. Sustain. Energy Rev. 26, 1087-1100. 